\title{
An Analysis of Turkey's Prospective Membership in the European Union from a 'Security' Perspective
}

\author{
H. TARIK OĞUZLU* \\ Bilkent University, Ankara, Turkey
}

\begin{abstract}
This article argues that it is possible to explain the European Union's reluctant attitude towards Turkey's membership in the EU on the basis of the EU's international and security identity and Turkey's security culture and perception of Europe. The EU's final decision on Turkey's accession is dependent both on Turkey's performance in adopting the EU's distinctive security identity and on the continuation of the EU member-states' commitment to turning the EU into an international actor with vital security interests in Turkey's vicinity. On the basis of this reasoning, the article reaches two main conclusions. The first is that the prospects for Turkey's EU membership are better in the post-11 September era than they were in the 1990s. The second is that there is a close relationship between the way the EU accession process unfolds and the way Turkey and the EU see each other. The longer the accession process lasts and the more ambiguously the EU reacts towards Turkey's membership, the more likely Turkey and the EU will view each other as 'security threats' rather than 'security providers'.
\end{abstract}

I HE MAIN ARGUMENT OF THIS ARTICLE is that one cannot make a convincing analysis of Turkey's EU membership prospects without uncovering the security rationales of Turkey and the European Union with regard to each other. From the earliest encounters between the two sides, a security-based rationality has been decisive in setting the tone of mutual relationships. Prior to this, and until the end of the Ottoman Empire, Europe and Turkey had perceived each other mainly as enemies and rivals (Neumann, 1999: 39-63).

This situation was faced with a critical challenge in the early 1920s as the founders of the Turkish Republic decided to break with the legacy of relations between Europe and the Ottoman Empire by turning the direction of the country towards Europe as the ideal destination of civilization and 
modernization. The Europe-friendly features of Turkish foreign policy during the tenures of Mustafa Kemal Atatürk and İsmet İnönü were solidified in the aftermath of World War II, as Turkey and the Western European states stood shoulder to shoulder as NATO allies against the common threat of communism. The intergovernmental nature of NATO membership, the existence of the common external enemy and Turkey's contribution to the realization of Europe's strategic security interests prevented the Europeans from perceiving Turkey as an 'other' throughout the Cold War years. Turkey was considered to be a part of Europe's 'self' (Aybet \& Müftüler-Baç, 2000).

However, this cooperative togetherness started to change with the advent of the post-Cold War era, as the contours of European-ness began to be defined by membership in the European Union (Diez \& Whitman, 2002). Despite all of Turkey's attempts to join the EU as a full member, the latter seems to have adopted a highly critical view on this issue. Even though a number of economic, social, cultural and political factors might account for the greater part of the EU's negative attitude towards Turkey's full membership (Müftüler-Baç, 1997), the emphasis here will be on geopolitical and security-related ones. This is not to claim that these factors supplant the others: they simply supplement them in an endeavour to produce a clearer picture of Turkey-EU relations.

This article will first of all examine the EU's distinctive international and security identity in order to explain the EU's geopolitical and securityrelated concerns vis-à-vis Turkey's membership. Attention will then focus on the logic of the EU enlargement process, with a view to highlighting the close link between the EU's international identity and the terms of the EU accession process. Afterwards, the analysis will focus on Turkey's perception of Europe and the EU accession criteria in view of Turkey's security culture. The article will have two major conclusions. The first is that Turkey's EU membership prospects seem to be more promising in the post-11 September era than they were during the 1990s. The second is that there is a close relationship between the way the EU accession process unfolds and the way Turkey and the EU see each other. The longer the accession process lasts and the more ambiguous the EU reaction towards Turkey's membership, the more likely Turkey and the EU will be to view each other as 'security threats' rather than 'security providers'.

\section{The International Identity of the European Union}

The main contention of this section is that the evolution of the European Union in the fifty or so years since the onset of Cold War era has resulted in a distinctive security tradition in Europe. Without understanding this, one 
cannot hope to comprehend the current logic of the EU accession process, because the EU's accession criteria are constituted by its distinctive security identity. The EU-based Europe, in the aftermath of World War II, was no longer a conglomerate of fully independent states with their distinctive domestic and foreign attributes preserved. Indeed, the EU's integration process started to change the rules of the Westphalian interstate order in Europe by rendering the logic of balance-of-power politics redundant (Wæver, 1998a).

While it is mostly claimed that NATO was the main security organization during the Cold War years, one should not underestimate the role of the EU in the maintenance of peace and security in Western Europe (Wæver, 1998b). Forming a collective defence alliance against the Soviet Union proved to be much easier than the efforts to address the balance-of-power logic among the old belligerent powers of Western Europe. The latter became possible through the 'politicization' of potential security issues. The logic was that if potential security issues were cast in political terms, it would be more difficult for power-holders to conceptualize them as security issues, which would necessitate the threat and use of force in their eradication. Politicization of potential security issues could enable the participants to reach compromise solutions (Wæver, 1997). The hope was that if Europeans managed to 'politicize' - rather than 'securitize' - potential security issues in the domestic arena, they would more easily repeat the same practice in the international arena.

However, the crucial point in this regard was, and still is, that a successful 'desecuritization' process - which requires a more inclusive self-other relationship - could become possible only within the post-sovereign and quasiimperial institutional environment of the EU (Wæver, 1998b). Given this line of thought, if a state remained a unitary, highly authoritarian, overtly centralized and unicultural polity, it would be nearly impossible for it to be admitted to the EU, since it would be difficult for a successful domestic and external politicization process to take root in such a polity. The supranational characteristics of the EU's institutional environment would make life easier only for states that were content with diffusion of sovereignty and pluralization of the domestic political order.

Built upon this Cold War legacy, the 1990s have seen the EU evolve into a composite civilian-normative international actor, rather than military one that mainly exhibits the qualities of a strategic security actor. While the EU's civilian power emanates from the huge economic resources of the EU members at its disposal, its normative power originates from its ability to determine the confines of 'normalcy' and 'appropriate state behaviour' in global international society (Manners, 2002). The best place to observe this is in the EU accession processes, where aspirant countries willingly adapt their socio-economic and political structures to existing EU norms. 
Despite all this, one can still claim that today's EU also possesses the traits of an embryonic military actor. Since the Maastricht Treaty of 1991, the EU has taken some important steps along this route. Following their failures in the territories of the former Socialist Republic of Yugoslavia, the memberstates of the EU have stepped up their efforts to endow the EU with the military means necessary to play an efficient role in the management of conflicts, at least in Europe.

However, on balance, today's EU is more of a normative-civilian actor than a global military one. There is still a certain lack of cohesion among EU members with regard to the geopolitical and strategic priorities of the Union. In geopolitical terms, it seems that the members, particularly those with an imperial legacy, have more actor-ness than the EU itself as an institution. For instance, France and the United Kingdom, two former imperial powers, have led the way in the evolution of the EU's foreign and defence policy (Rasmussen, 2002: 54). Besides, the EU's determination to make operational a rapid reaction force of 60,000 by the end of 2003 might seriously founder on the low military budgets of the member-states (Kapstein, 2002).

Though one can safely claim that the EU is gradually evolving into an international actor with a military logic, this in no way accords with the expectations of the classic realpolitik understanding of security. This is mainly due to the fact that the security interests of the EU are achieved through simultaneous processes of deepening and widening (see Larsen, 2002). Moreover, the European Security and Defence Policy aims at the establishment of a European Rapid Reaction Force, dubbed the European Army, for tasks of humanitarian intervention, peacekeeping and conflict management. The lower end of the Petersberg tasks did not envisage the creation of a European army with war-fighting capabilities and capable of being deployed in any part of the globe. The major goal of the European Army has been to enable EU members to respond to any former Yugoslaviatype crises that may occur within the European continent in future (Rasmussen, 2002: 54).

It seems that the EU's approach towards the European Army is in accordance with its security understanding and threat perceptions in the post-Cold War era. It has been observed that the security referents within postWestphalian Europe have gradually become 'society' and 'individuals', rather than the 'nation-state' (Buzan, Wæver \& de Wilde, 1998: 23-24). The EU member-states share the view that today's world poses no conventional threats to Europe's security. To them, the sources of new threats and risks to European security lie in the unstable regions along the peripheries of Europe. Problems that might emanate from the unhealthy domestic structures of these peripheral countries include immigration, ethnic intrastate wars, environmental pollution, drug-trafficking, organized crime and so on (Sjursen, 2001). 
This security logic also manifests itself in the EU's approach towards the use of force in dealing with terrorist or other non-conventional security threats. The European Union has adopted a rather more selective approach towards both the definition of terrorism and the way to deal with it. The EU refuses to define all forms of anti-Western (anti-US, anti-EU) and anti-regime political activities in the 'weak' and 'failed' states of the Greater Middle Eastern region as 'terrorism'. And in cases where activities are defined by the EU as terrorism, the Union tends to deal with them through a policy of 'engagement' rather than 'containment'. European circles question whether it is possible to eradicate terrorism from the earth without initially rooting out the socio-political structures that lead to the (re)production of terrorist activities (Hoffman, 1999).

As for military instruments, the EU members tend to conceptualize these as means for paving the way for the efficient implementation of a strategy of 'structural development'. If EU development aid to unstable regions around Europe's peripheries is to be successful in rooting out the structural causes of instability and terrorism, the EU will need at times to rely on military means (the European Army) (Cornish \& Edwards, 2001). The main reason that EU members are inclined to rely on soft-security measures in their struggles with terrorism is the EU's civilian security culture, which does not idealize the establishment of a war-making European army on a global scale (Larsen, 2002).

On the basis of this distinctive conceptualization of security within the EU area, one can safely suggest that Turkey's accession to the EU might prove impossible from a security perspective in the short run. Turkey seems to be too hard a security actor to be digested within the EU's soft-security environment. Furthermore, a great majority of European security analysts concur that Turkey's inclusion within the EU might increase 'conventional threats' to European security (Buzan \& Diez, 1999). To Turkey-sceptic eyes, Turkey's EU membership also constitutes another kind of security threat, because Turkey's accession would have a divisive impact on the EU's internal integration process (Wæver, 1995). Overall, when Turkey's realpolitik security and foreign policy practices and its non-European cultural and social characteristics are taken together, a great number of Europeans tend to view Turkey's inclusion within the EU as an inhibiting factor in relation to the EU's deepening and widening processes.

\section{The Logic of the Accession/Enlargement Process}

The main functions of the EU's accession process are twofold. One is to preserve and promote the peculiar security identity of the European Union, the 
other to pave the way for the transformation of the EU into an international actor that differs from other global actors on the basis of its distinctive security modelling.

For any country to join the EU, the first requirement is adoption of the conceptual basis and dynamics of the EU's security modelling. It is only through this that the EU can feel secure against possible sources of threat that may originate from the EU's periphery (Engelbrekt, 2002). The widening of the EU has been not only an end, but also a means intended to enable the EU's members to transform their club into a more powerful international actor in the global arena.

Seen in this light, it is neither the performance of the candidate countries in meeting the accession criteria per se nor their mere geopolitical and geostrategic significance, but rather the EU's ability to absorb them into the EU's international identity that appears to define the EU's response towards enlargement (Grabbe, 2002). From this perspective, one could read the EU's accession process as a special EU strategy aimed at transforming the sociopolitical, economic and security make-up of candidate countries in such a way that their future accession to the EU would not create great obstacles for the EU's emerging identity and institutional setup. In sum, the more difficult it is to absorb a given country into the EU, the more ambiguous and detailed the accession criteria adopted by the EU towards that particular country. This is a rational course of action that fits well with the EU's post-Cold War deepening process.

\section{Turkey's Perception of Europe and the EU Accession Process in View of Its Security Culture}

In analysing the prospects of Turkey's EU membership from a security perspective, one should also examine Turkish perceptions of Europe and the EU accession process. In doing this, this article will set out two interrelated arguments. One is that the centuries-old Ottoman Empire-Europe interaction process shaped and constituted Turkey's security understanding (see Karaosmanoğlu, 2000). The other is that there is a close relationship between Turkey's security culture and the way Turkey reacts to the EU accession process.

The Republican elite perceived Europe mainly from a security perspective that is highly embedded within an ideational logic. More specifically, the Turkish elites were of the view that in order for Turkey to preserve its territorial integrity and external sovereignty, interstate relations between the new-born Republic and the major European powers needed to be friendly. It was clear to them that if they did not want to see the destiny of the Ottoman 
Empire repeated, the enmity- and rivalry-based Europe-Turkey interaction process needed to be replaced with a friendship-based one. Their hope was that if the European states perceived Turkey as European, they would not have to construct their relations with Turkey on the basis of a self-other dichotomy. Seen in this way, one can claim that Turkey's Europeanization efforts are strongly bound to the goal of state survival.

There were two ways for the Republican elite to prove Turkey's Europeanness and thus to achieve the ultimate goal of survival. The first consisted of efforts to transform the internal make-up of Turkish society in accordance with the European norms of the time. The second was to follow a Europefriendly foreign policy by joining European intergovernmental institutions, of which security-related ones were privileged (see Bozdağlioğlu, 2001: 76-117). On balance, the second option was given primacy because this was the cheapest and the most cost-efficient way of having Turkey's European identity recognized by the Europeans.

Inspired by the late 19th-century positivist credentials of European nationalism, the Republican elites adopted an instrumental view towards Europe in their efforts to eradicate the roots of 'multi-ethnicism' and 'politicization of religion' inside Turkey (Mayall, 1997: 22-25). They were helped in this process by the fact that Europe at that time viewed 'secularism' and the 'homogenous nation-state' as among the most important constitutive norms of the European state system.

The Turkish elite were of the view that a stable and secure Turkey-Europe relationship would consist of the following principles: neither of the parties would interfere with the domestic affairs of the other; each party would take the utmost care to respect the territorial integrity and national sovereignty of the other; both sides would join forces against common enemies; and Turkey, as the weaker party of the relationship, would act to preserve and promote European strategic interests in the Eastern Mediterranean and Middle Eastern regions.

Based on this particular understanding of Europe-Turkey relations, Turkey's security culture reflected the following features: what needed to be secured were primarily the territorial integrity and national sovereignty of the country and the secular, unified and homogenous features of the nationstate; Turkey's main external security priorities were to preserve the gains of the 1923 Lausanne Peace Treaty and the 1960 agreements on Cyprus; in order for Turkey to feel secure, its strategic preponderance in the Aegean and the Eastern Mediterranean needed to be maintained and its European identity should be recognized by the Europeans; the terms of the Sèvres Treaty of 1920 were not to be reimposed on the Turkish nation; and Turkey must never feel encircled and abandoned.

In the aftermath of the Cold War era, there were no radical changes to Turkey's security mentality and perception of Europe, even though the 
Europe of the 1990s was fundamentally different from the Europe of the prewar years. The ruling Turkish elite continues to regard developments outside its borders as security threats to its national integrity and territory. For instance, Russia's aggressive and assertive policies in Central Asia and the Caucasus and the attempts of Turkey's Middle Eastern neighbours to develop weapons of mass destruction and ballistic missiles to deliver them have been considered as conventional threats to Turkey's security (BazoğluSezer, 1992). In addition, when the survival of the homogenous and secular nation-state was defined as the main security referent, it was not difficult for the Turkish elite to define Kurdish separatism and political Islam as the greatest threats facing the country. ${ }^{1}$

Turkey continued to regard its alliance relationship with the United States within NATO as the most important link in terms of shoring up its Western identity and national security. Therefore, Turkey's major concern during the post-Cold War era has centred on the question of what will happen if the Atlantic alliance loses its collective defence characteristic so irreversibly as to contribute to dilution of the commitments under Article 5 of the Washington Treaty. Would Turkey continue to feel secure if membership in the new NATO, including the countries of Central and Eastern Europe and maybe even Russia, represented membership in a collective security organization rather than a collective defence one?

In fact, Turkey's membership of NATO has shaped, and to a specific degree constituted, its perception of the West in general and Europe in particular. ${ }^{2}$ The fact that Turkey stood on a par with the European allies within a Europecentred intergovernmental NATO during the Cold War years seems to have led the Turkish elite to believe that the European state system has not fundamentally diverged from Westphalian principles. One can clearly see this Turkish view in connection with the European Army. Having underestimated the impact of the EU's supranational integration process and distinctive security identity on the Europeans' attempt at building an army, Turkey has rushed to join the European Army as a contractual party. Turkish elites have interpreted EU actions in this regard as well-designed attempts at transforming the supranational EU into an intergovernmental global security actor. For the majority of them, participation in such an intergovernmental European security institution would imply confirmation of Turkey's 'European' identity, under a logic that resembles the reasoning behind Turkey's approach to NATO. Inspired by this mentality, some have even argued that the EU agreed to Turkey's candidacy in Helsinki in 1999 because of Turkey's half-century-long NATO membership, advanced military capabilities and significant geostrategic location (Müftüler-Baç, 2000). However, it should be

1 The National Security Policy Document of 1997, prepared by the Turkish General Staff, mentions Kurdish separatism and radical Islam as the number one and two domestic security threats; see Jenkins (2001: 48).

2 The author is grateful to one of the anonymous reviewers for Security Dialogue for this point. 
emphasized that candidacy is something fundamentally different from full membership. The fact that strategic considerations may have played a role in Turkey's candidacy and its placement in the EU's orbit should not lead one to mistake candidacy for membership.

In response to the EU's negative stance on its participation in the decisionmaking mechanisms of the emerging European Army as an equal party, Turkey has long vetoed the EU's right of assured access to NATO assets (Missiroli, 2002). Turkey has approached this issue from an instrumental perspective, believing that the credentials of Turkey's European identity will erode if Europe no longer desires Turkey's participation in European security institutions. Such an erosion would in turn exacerbate Turkey's security concerns, with the likely possibility that Europe might be considered more as a 'threat' than a 'security provider'.

In view of this security culture, the Turkish ruling elite has not always interpreted the conditions put forward by the European Union positively. In principle, full democratization, the creation of a liberal economic order and adoption of the EU's Community Law have all been regarded by the Turks as legitimate EU demands. However, some aspects related to Turkey's domestic and external context have given rise to anxiety. Delegation of sovereignty to supranational EU organs in Brussels and substate authorities inside the country, recognition of the Kurdish citizens of Turkey as a distinct minority group with guaranteed rights to education and publication in their mother tongue, and the use of EU-induced political pluralism by political Islamists and Kurdish separatists are anathema to the Kemalist state elite. ${ }^{3}$

Trapped in the infamous 'Sèvres Syndrome', the Turkish ruling classes have viewed the granting of more authority to local administrations and recognition of the cultural, social and educational rights of different ethnic communities as moves against the unitary nation-state character of the Turkish Republic. To them, if EU membership were to result in increased pluralization and liberalization of the political structure, with the unitary character of the Turkish nation-state strongly challenged, then the EU accession process would constitute one of the greatest threats to the national interests. Both preservation of the territorial integrity of the country and maintenance of the secular democratic credentials of the republic are deemed by the establishment elite as 'nationally sensitive' issues. ${ }^{4}$ In the view of the establishment, both partitionist Kurdish fractions and fundamentalist Islamist groups would find a niche in Turkey's prospective membership in the EU.

\footnotetext{
3 Turkey recognizes only the Christian and Jewish subjects of the state as minorities. The Treaty of Lausanne of 1923 defines minority status on the basis of religious difference.

${ }^{4}$ See the opening speech of Sabahattin Çakmakoğlu, Turkey's Minister of National Defence, at the ASAM (Eurasian Strategic Studies Centre) Conference on Globalization, Security and Nation-State, Ankara, 15-16 June 2002.
} 
However, the issue that seems to have created the greatest pressure on the Turkish elite has been the EU's demand that Turkey settle all its territorial disputes with Greece over the Aegean Sea and Cyprus by the end of 2004. If the Greek Cypriots join the EU before Turkey and as representatives of the whole of Cyprus, and if the Aegean disputes are decided by the International Court of Justice in The Hague in line with Greece's interests, Turkey will feel that it has been encircled in strategic terms by the European Union and Greece. Given that one of the pillars of Turkey's security culture consists of the continuation of the strategic balance with Greece in and around the Aegean Sea and Cyprus, Turkey has hastily interpreted the EU accession process as a threat to Turkey's security because further 'Europeanization' would result in the loss of Turkey's relative strategic advantages vis-à-vis Greece (Barlas \& Turan, 1999).

\section{Turkey's Security Culture and the Attractiveness of Non-EU Options}

One important factor that seems to inhibit Turkey's internalization of the EU's security identity is its close strategic relationship with the United States in Eurasia, Central Asia and the Greater Middle East. However, it should be noted that this foreign policy course was not Turkey's first option but gradually came into being as the European Union turned down Turkey's membership application. Even though the majority of the political parties and the public have advocated Turkey's EU membership, they have found themselves backing non-EU alternatives as they perceived the EU to be discriminating against Turkey. ${ }^{5}$

Nevertheless, there have also been other factors that have facilitated the likely implementation of such a non-EU option. First, the security culture of the Turkish Republic made it possible to cooperate with the United States in the above-mentioned regions. Both Turkey and the United States are used to operating in the international arena in accordance with the principles of realpolitik. Second, the 1990s witnessed an increase in quality across the whole range of Turkish-Israeli relations, which has fostered bilateral cooperation in economic, social and military areas. To mention one example, the two countries signed a sophisticated military agreement in 1996. These strategic relationships with the US and Israel have not represented an aberration in terms of Turkey's security culture. The three countries' threat perceptions vis-à-vis weapons of mass destruction and the ballistic missiles to deliver them have been similar. Third, US administrations have not forced

${ }^{5}$ The author would like to thank one of the anonymous reviewers for Security Dialogue for this point. 
Turkey to undergo a radical transformation process in order to become a model for the newly established states in the region. To them, the secular and homogenous nature of the Turkish nation-state was a good model for those countries to emulate. For the USA, Turkey's stability has always come before Turkey's democratization (Kramer, 2000: 223-231). Fourth, US interests in the above-mentioned regions have most of the time coincided with those of Turkey. And, fifth, US administrations have always expressed support for Turkey's march to the EU, ${ }^{6}$ and have played the role of consoling Turkey when it has been rebuked by the Europeans.

\section{Prospects after 11 September: Anything New?}

Turning to developments in the post-11 September era, one can rightfully claim that Turkey's chances of being included within the EU have radically increased from a security perspective. There are a number of convincing reasons why the EU should offer Turkey a clear membership prospect.

First of all, if the ideational boundaries of Western civilization, of which the EU constitutes an important part, are defined by the struggle against global terrorism, then Turkey's case for EU membership will likely become stronger. This is so because Turkey has struggled with separatist and fundamentalist terrorism for decades.

Second, if the European Union wants to see its security interests preserved and its security model applied to the global struggle with terrorism, then Turkey's incorporation into the EU family is highly significant. This is so mainly for the following reasons. The post- 11 September era has increasingly exposed Europe to the challenges of global terror. Given that the sources of global terrorism mainly originate from the Middle East, Turkey's inclusion within the EU would enable the latter to rely on Turkey's advanced military capabilities in its struggle with such threats. Turkey's membership in the EU would bolster the claims of those who argue that the war on terrorism should not be continued on the basis of a clash of civilizations between the developed Christian North and the undeveloped Muslim South. Moreover, Turkey's EU membership would also imply that it is not predestined that a country whose population is overwhelmingly Muslim and whose economic power lags far behind those of the developed countries can never join the EU, currently a Christian club of developed European states.

Third, if the EU's security is based on efforts to embrace and engage with regions to the East and South, the EU will not be able to achieve ultimate security by fixing its borders at some definite point and excluding a number

6 This US attitude could easily be seen during the EU's Helsinki Council. At that time President Bill Clinton made numerous phone calls to various European leaders in a bid to argue for Turkey's EU candidacy. 
of countries outside the EU area (Richmond, 2000). Thought of this way, leaving Turkey outside the EU and treating it as a barrier against soft (more dangerous) and hard (less dangerous) security threats will not operate in today's environment because of the globalized and trans-regionalized nature of security issues in this special part of the world (Eralp, 2000). If Turkey were to implement all the steps envisaged under the conditions of its EU accession process but the latter did not admit the former into membership, threats of a soft security nature to the EU's stability and prosperity would abound.

It seems that there is a close relationship between the quality of Turkey's accession process with the EU and the quality of the EU's security feeling. The further Turkey's domestic structures depart from those of the EU, the more turbulence and chaos takes place inside the country. The more internal instability takes root in Turkey, the less secure the EU will feel because the kind of security threats that the EU is trying to eliminate would abound.

Fourth, if the transatlantic rift between the EU and the USA further widens in the years to come (Kagan, 2002), Turkey's placement in this equation will become fundamentally important for the EU. If Turkey continues to ally with the United States and Israel in the region, this would certainly curb the potential geopolitical influence of the EU. After all, what would be at stake would be the promise of EU's security model. The danger for the EU is that if Turkey were included in the US model, this would curtail the success of the EU members in terms of both sustaining their model of security in Europe and transferring it to the peripheries of the continent. In the long run, this would contribute to the erosion of EU's security feeling in the region.

What follow now are some of the positive developments in EU-Turkey relations that seem to reflect the mood of the post-11 September era. First off all, during its Laeken Summit in December 2001 the European Union invited Turkey to take part in the European Convention scheduled for April 2002. This was a remarkable development given that the EU prior to 11 September had refused to issue an invitation to Turkey, even though it had invited all the other candidate countries.

Second, Turkey, implicitly or explicitly, encouraged Rauf Denktash, President of the Turkish Republic of Northern Cyprus, in his efforts to restart face-to-face talks with President Clerides of the Greek Cypriot Administration on 16 January 2002. This was an important about-turn on the Turkish side because Denktash had refused to sit at the same table as Clerides unless the sovereignty of the Turkish Republic of Northern Cyprus was recognized beforehand.

Third, Turkey and the EU were able to finally reach an accord over the thorny issue of NATO's assets around the time of the EU's Copenhagen Summit in December 2002.7 Though the Greek government vetoed the so-

7 The text of the EU-NATO Declaration on ESDP is available at http://www.nato.int/docu/pr/2002/p02142e.htm. 
called 'Ankara Understanding' during the EU's Laeken Summit in December 2001 (Missiroli, 2002), the sides were finally able to resolve the main frictions a year later. According to the new arrangement, Cyprus will remain outside the area of responsibility of the EU's Rapid Reaction Forces, while Turkey will lift its veto on the EU's assured access to NATO's assets. Behaving in this way, Turkey has proved that its intentions were not to contribute to further intra-Alliance divisions but to make sure both that the EU's evolving security structure develops in close cooperation with NATO and that the process of Turkey's accession to the EU accelerates.

Fourth, the EU finally came to an understanding with Turkey over the incorporation of the Kurdistan Workers Party (PKK) and other leftist groups into its list of terrorist organizations. This might augur well for the prospect of Turkish-EU cooperation against terrorism. However, the challenge lying ahead for EU-Turkey relations in this regard concerns the EU's attitude towards KADEK, the organization established in the aftermath of Turkey's victory over the PKK. Here, the question is whether the European Union will heed Turkey's claims that KADEK and the PKK differ only in terms of means, not ends, and outlaw KADEK.

Fifth, Turkey and the European Union have had to realize that their interests in the Middle Eastern Region are not so divergent as some Turkish and European circles used to believe. In the face of US attempts to depict the Iraqi and Iranian regimes as members of an 'Axis of Evil', Turkey and the EU member-states, with the exception of the United Kingdom, share the belief that 'engagement', not 'containment' and 'pre-emption', would be the most appropriate mechanism for dealing with these regimes. If they succeed in cooperating over Iraq, Iran and the Caucasus, this might strengthen the argument of those who assert that if the EU aims at becoming an important international actor in the regions surrounding Turkey, Turkey's inclusion in the EU would be of great help.

Sixth, the Turkish Parliament passed radical laws in early August 2002 in an attempt to adapt Turkey's laws to the EU Community Law. This shows that there is a willingness on the part of Turkey to internalize the constitutive norms of the EU's security modelling. In line with these latest regulations, the use of non-Turkish mother tongues in education and broadcasting has been allowed. Furthermore, the new National Strategy Document, also adopted in August, dropped Greece from the list of prime threats to national security.

\section{Conclusion}

Despite all these optimistic developments following the portentous events of 11 September 2001, if the EU does not commence accession talks with Turkey 
- particularly on the pretext that a solution to the Cyprus dispute was not reached owing to the intransigent and uncooperative stance of the Turkish Cypriots and Turkey - then one might expect a gradual deterioration in the quality of Turkey-EU security relations. ${ }^{8}$ This would be the case because as long as the accession process drags on, and as long as this process is built on vague promises of membership for Turkey, the probability that Turkey and the EU will view each other as 'security threats' will increase. From Turkey's perspective, 'exclusion' from the EU would accentuate 'difference' from the $\mathrm{EU}$, and 'difference' from the EU would increase the probability of 'conflict' with the EU.

In sum, Turkey's EU membership prospects will sky-rocket if the ongoing accession process succeeds in paving the way for Turkey's adoption of the EU's distinctive security identity and if the EU member-states do not lose their penchant for turning the Union into an international actor with vital security interests in Turkey's vicinity.

* The author is a PhD candidate at Bilkent University, Ankara, and holds a MSc in international relations from the London School of Economics and Political Science and an MA in international relations from Bilkent University. His e-mail address is oguzlu@bilkent.edu.tr.

\section{References}

Aybet, Gülnur \& Meltem Müftüler-Baç, 2000. 'Transformations in Security and Identity After the Cold War: Turkey's Problematic Relationship with Europe', International Journal, Autumn 2000: 567-582.

Barlas, Dilek \& İlter Turan, 1999. 'Turkish-Greek Balance: A Key to Peace and Cooperation in the Balkans', East European Quarterly 32(4): 469-489.

Bazoğlu-Sezer, Duygu, 1992. 'Threat Perceptions in Southern Europe: The Case of Turkey', in Laszlo Valki, ed., Changing Threat Perceptions and Military Doctrines. London: Macmillan (227-237).

Bozdağlioğlu, Yücel, 2001. 'Identity and International Relations: Turkish Foreign Policy in the Post-World War II Era', unpublished PhD dissertation, University of Kentucky.

Buzan, Barry \& Thomas Diez, 1999. 'The European Union and Turkey', Survival 41(1): 41-57.

Buzan, Barry; Ole Wæver \& Japp de Wilde, 1998. Security: A New Framework for Analysis. Boulder, CO: Lynne Rienner.

Cornish, Paul \& Geoffrey Edwards, 2001. 'Beyond the EU/NATO Dichotomy: The Beginnings of a European Strategic Culture', International Affairs 77(3): 584-603.

${ }^{8}$ On the basis of the European Commission's Strategy Paper, in which the Commission recommended that the European Council should not commence accession talks with Turkey primarily because Turkey has not fully met the short-term political criteria laid out in the Accession Partnership Document, the EU Council in Copenhagen in December 2002 refused to mention a specific date for the start of accession talks with Turkey. 
Diez, Thomas \& Richard Whitman, 2002. 'Analysing European Integration: Reflecting on the English School Scenarios for an Encounter', Journal of Common Market Studies 40(1): 43-67.

Engelbrekt, Kjell, 2002. 'Multiple Asymmetries: The European Union's Neo-Byzantine Approach to Eastern Enlargement', International Politics 39(1): 37-52.

Eralp, Atilla, 2000. 'European Security and Turkey', Private View 8: 52-55; available at http://www.tusiad.org/yayin/private/spring00/eurosecurity.pdf (12 June 2003).

Grabbe, Heather, 2002. 'European Union Conditionality and the Acquis Communautaire', International Political Science Review 23(3): 249-268.

Hoffman, Bruce, 1999. 'Is Europe Soft on Terrorism?', Foreign Policy 115: 62-77.

Jenkins, Gareth, 2001. Context and Circumstances: The Turkish Military and Politics, Adelphi Paper 337. New York: Oxford University Press.

Kagan, Robert, 2002. 'Power and Weakness', Policy Review 113; available at http:/ / www. policyreview.org/JUN02/kagan.html.

Kapstein, Ethan B., 2002. 'Allies and Armaments', Survival 44(2): 141-155.

Karaosmanoğlu, Ali. L., 2000. 'The Evolution of Turkey's Security Culture and the Military in Turkey', Journal of International Affairs 54(1): 199-217.

Kramer, Heinz, 2000. A Changing Turkey: The Challenge to Europe and the United States. Washington, DC: Brookings Institution Press.

Larsen, Henrik, 2002. 'The EU: A Global Military Actor?', Cooperation and Conflict 37(3): 282-302.

Manners, Ian, 2002. 'Normative Power Europe: A Contradiction in Terms?', Journal of Common Market Studies 40(6): 235-258.

Mayall, Simon, V., 1997. Turkey: Thwarted Ambition, McNair Paper 56. Washington, DC: Institute for National Strategic Studies, National Defense University.

Missiroli, Antonio, 2002. 'EU-NATO Cooperation in Crisis Management: No Turkish Delight for ESDP', Security Dialogue 33(1): 9-26.

Müftüler-Baç, Meltem, 1997. Turkey's Relations with a Changing Europe. Manchester: Manchester University Press.

Müftüler-Baç, Meltem, 2000. 'Turkey's Role in the EU's Security and Foreign Policies', Security Dialogue 31(4): 489-502.

Neumann, Iver B., 1999. Uses of the Other: 'The East' in European Identity Formation. Minneapolis, MN: University of Minnesota Press.

Rasmussen, Mikkel Verdy, 2002. 'Turbulent Neighbourhoods: How To Deploy the EU's Rapid Reaction Force', Comparative Security Policy 23(2): 39-69.

Richmond, Oliver P., 2000. 'Emerging Concepts of Security in the European Order: Implications for "Zones of Conflict" at the Fringes of the EU', European Security 9(1): 41-67.

Sjursen, Helene, 2001. New Forms of Security in Europe, ARENA Working Papers WP 01/4. Oslo: University of Oslo Press.

Wæver, Ole, 1995. 'Identity, Integration and Security', Journal of International Affairs 48(2): 389-432.

Wæver, Ole, 1997. 'Insecurity, Security, and Asecurity in the West European Non-War Community', in Emanuel Adler \& Michael Barnett, eds, Security Communities. Cambridge: Cambridge University Press (69-118).

Wæver, Ole, 1998a. 'Integration as Security: Constructing a Europe at Peace', in Charles A. Kupchan, ed., Atlantic Security: Contending Visions. Washington: Council on Foreign Relations (45-63).

Wæver, Ole, 1998b. 'The EU As A Security Actor: Reflections from a Pessimistic Constructivist on Post-Sovereign Security Order', in Kjell A. Eliassen, ed., Foreign and Security Policy in the European Union. London: Sage (250-288). 